\title{
Collaborative research and the hunting in the Brazilian Cerrado: The case of Xerente Indigenous Land
}

\author{
Milton José de Paula ${ }^{1,5}{ }^{(}$, , Valcir Sumekwa Xerente ${ }^{2 *}$, Aion Angelu Ferraz Silva ${ }^{3}$, Bruno Spacek Godoy ${ }^{4}$ \& \\ Juarez Carlos Brito Pezzuti ${ }^{4}$ \\ ${ }^{1}$ Instituto Federal de Educação Ciência e Tecnologia do Pará, Rod Ernesto Alcyoli km 3 Estrada do Forte, \\ Altamira, PA, Brasil \\ ${ }^{2}$ Universidade Federal do Tocantins, Palmas, TO, Brasil \\ ${ }^{3}$ Instituto Federal de Educação, Ciência e Tecnologia de Minas Gerais, Sabará, MG, Brasil \\ ${ }^{4}$ Universidade Federal do Pará, Belém, PA, Brasil \\ ${ }^{5}$ Universidade Federal do Pará, Programa de Pós-Graduação em Zoologia, Belém, PA, Brasil \\ *Corresponding author: Milton José de Paula, e-mail: sdabupre@gmail.com
}

DE PAULA, M. J., XERENTE, V. S., SILVA, A. A. F., GODOY, B. S., PEZZUTI, J. C. B. Collaborative research and the hunting in the Brazilian Cerrado: The case of Xerente Indigenous Land. Biota Neotropica. 18(4): e20180556. http://dx.doi.org/10.1590/1676-0611-BN-2018-0556

\begin{abstract}
This paper presents a study of the hunting activities on Xerente Indigenous Land (XIL) in the Brazilian Cerrado. We used data from a Hunting Monitoring Program from eight villages to evaluate the effects of village age, distance from village to town and season (wet and dry) on the composition of hunted species, animals and biomass killed and availability of preferred game-species. We also assessed for any indication of fauna depletion around the villages. Distance from village to town and season were the only variables which affected composition. Preferred species occured more often in villages closer to the town. However, these villages present strong indications of local game-species depletion. The hunters' great capacity for spatial movement can eliminate this effect. Animals and biomass killed was high in the dry season. Game-species composition between seasons can avoid the overexploitation of some sensitive species, such as low-land tapir. These results are important in the design of local management and conservation plans. Our results also contribute to further understanding the impacts of hunting in open Neotropical environments.
\end{abstract}

Keywords: game fauna, indigenous, Cerrado, conservation, participatory monitoring.

\section{Pesquisa Colaborativa e a Caça no Cerrado Brasileiro: O caso da Terra Indígena Xerente}

Resumo: Este artigo apresenta um estudo sobre a atividade de caça na Terra Indígena Xerente (TIX), Cerrado brasileiro. Utilizamos dados do Programa de Monitoramento de Caça em oito aldeias para avaliar os efeitos da idade da aldeia, a distância da aldeia para cidade e a estação (úmida e seca) sobre a composição de espécies caçadas, animais e biomassa abatidos e a disponibilidade de espécies preferidas para o consumo. Também avaliamos a indicação de depleção da fauna ao redor das aldeias. Distância da aldeia para a cidade e estação foram as únicas variáveis que afetaram a composição das espécies. Espécies preferidas ocorreram mais frequentemente em aldeias mais próximas à cidade. No entanto, essas aldeias apresentam fortes indicativos de depleção local das espécies. Entretanto, a grande capacidade de locomoção dos caçadores pode eliminar esse efeito. Animais e biomassa abatidos foram maiores durante a estação seca. A composição das espécies cinegéticas entre as estações pode evitar a exploração excessiva de algumas espécies sensíveis, como a anta. Esses resultados são importantes na elaboração de planos locais de manejo e conservação. Nossos resultados também contribuem para o melhor entendimento dos impactos da caça em ambientes neotropicais abertos.

Palavras-chave: fauna cinegética, indigenas, Cerrado, conservação, monitoramento participativo. 


\section{Introduction}

Indigenous people of the Neotropics depend on the exploitation of natural resources for their livelihoods, needing to hunt for their subsistence and maintenance of their social structures (Fragoso et al. 2000, Nasi et al. 2008, Luzar et al. 2012, Shepard 2014, Iwamura et al. 2014). The manner in which this exploitation is performed is related to several factors, such as ecological drivers (e.g., species abundance), physical environment (spatial and climate), logistical apparatus (e.g., effort expended in the hunt), available technology (e.g., firearms use) and cultural constraints (e.g. taboos and food preferences) (Hill et al. 1997, Read et al. 2010, Luzar et al. 2012, Shepard et al. 2012). There is an extensive literature about indigenous hunting which has approached these factors, identifying the impacts on exploited wildlife as well as on the social organization of these societies (e.g. Alvard et al. 1997, Hill et al. 1997, Leeuwenberg \& Robinson 1999, Souza-Mazurek et al. 2000, Fragoso et al. 2000, Koster 2008, Constantino et al. 2008, Read et al. 2010, Shepard et al. 2012, Iwamura et al. 2014, Constantino 2015, 2016).

These factors may explain the hunting efficiency and availability of game species. The distance between settlement and kill site is used as an indicator of the abundance of the exploited species (Constantino 2015). If hunters kill most of their prey near to villages, it is assumed that exploited populations are representative and still available (Read et al. 2010, Strong et al. 2010, Constantino 2015), however if hunts occur far from villages, this indicates that exploited animal populations are depleted closer to villages (Hill et al. 1997, Souza-Mazurek et al. 2000, Constantino 2015). The availability of prey may be related to the climate. The Ache hunters and gatherers from Paraguay show an increased rate of finding main game-species during the dry season (Hill et al. 1997).

Village age and size, environmental integrity of the surroundings, hunting pressure history and distance to urban centers, may be relevant drivers in affecting the availability of preferred game species for consumption (Escamilla et al. 2000, Souza-Mazurek et al. 2000, Jerozolimski \& Peres 2003, Constantino et al. 2008, Constantino 2016). If there are indications these factors are driving decreases in the availability of game species, this may disturb the social organization of these societies and their interaction with the animals and environment (Milner-Gulland et al. 2003, Shepard et al. 2012, Iwamura et al. 2014).

In a synthetic framework these individual and synergistic factors are important in the understanding of wildlife exploitation by indigenous people. However, previous studies typically focused on forest environments, with few studies conducted in open environments, such as Brazilian Cerrado Savanna. For example, studies with the indigenous Xavante people observed that their hunting activity intensifies during the dry period, and that fire is an important tool in their hunting activities (Leeuwenberg \& Robinson, 1999, Fragoso et al. 2000, Welch et al. 2013). Another example comes from a study on the spatial patterns of indigenous hunting communities that occupy savanna and forest environments in Guyana. One of the results found was that the communities from savanna environments travel greater distances in their hunts compared to those from forest environments (Read et al. 2010).

The Xerente indigenous group inhabits the Cerrado biome of northern Brazil, and for the duration of one year took part in hunting participatory monitoring (HMP) (de Paula et al. 2017) in order to build a sustainable program for fauna exploitation. In this study we used the results of collaborative-research to evaluate the impact potential of some anthropogenic and environmental variables on hunted wildlife.
In accordance with the literature, we evaluated the effects of village age and size, distance from village to town and season on the composition of hunted species and availability of preferred game-species. We then assessed if there were any indications of fauna depletion around the villages. To determine this, we evaluated if the distance from village to town affects the occurrence of hunting events, and if these hunt events occur further from villages. In addition, we evaluated whether season affected the number and biomass of killed species.

\section{Material and Methods}

\section{Study area}

The Xerente Indigenous Land (XIL) (9³4’37,4” S, 4306’38,3” W) is located in Tocantínia municipality, Tocantins State, Brazil, covering an area of approximately $2,884 \mathrm{~km}^{2}$ (Figure 1). The Xerente belong to the Jê linguistic Family and Akwẽ language speakers, comprising the Jê-Centrais indigenous group. Their population in 2016 reached 3860 (Fundação Nacional do Índio 2016, unpublished data), currently distributed throughout 62 villages. The region is located within the Cerrado biome, and the XIL presents several phytophysiognomies: dense cerrado, typical and thin, rupestrian fields and path (savanna environment), cerradão and gallery forest (forest environment) (Ribeiro $\&$ Walter 2008). The region's climate is humid with moderate water deficit, an average annual temperature of $28^{\circ} \mathrm{C}$, and average annual precipitation between 1,700 to $1,800 \mathrm{~mm}$ (SEPLAN 2008). The pluviometric distribution presents climatic seasonality, alternating between the rainy season (November to April) and the extremely dry season (May to October).

The XIL within proximity to seven towns and is surrounded by a mosaic of anthropogenic landscapes including pasture, monocultures, and hydroelectric infrastructure (see Figure 1). XIL is the main protected area in the region, protecting significant amounts of natural vegetation. However, access to this area is facilitated by unpaved state roads (see Figure 1) connecting towns and serving as an outflow route for the region's agricultural output.

\section{Data collection}

\section{Hunting data}

Hunting data was collected through the HMP carried out in ten villages during a one year period (Mar. 2014 to Feb. 2015) (de Paula et al. 2017). Fifty-two hunters/monitors ( $91 \%$ of all hunters in the 10 monitored villages) contributed to the program, recording data about their own hunting activities on standardized monitoring sheets. For this study, we included data from only eight villages, as we used a base village with 10 or more recorded hunting events. Only species contributing at least 10 individuals or $1 \%$ of the killed biomass were included, with the exception of Tapirus terrestris (lowland tapir) which represented only nine kills but $35 \%$ of total killed biomass. Thus, 11 large and medium-sized mammals and one bird were chosen: Cuniculus paca (paca), Dasyprocta sp. (agouti), Dasypus novemcinctus (nine-banded armadillo), Hydrochoerus hydrochaeris (capybara), lowland tapir, Mazama americana (red brocket deer), Mazama gouazoubira (brown brocket deer), Nasua nasua (coati), Ozotoceros bezoarticus (pampas 


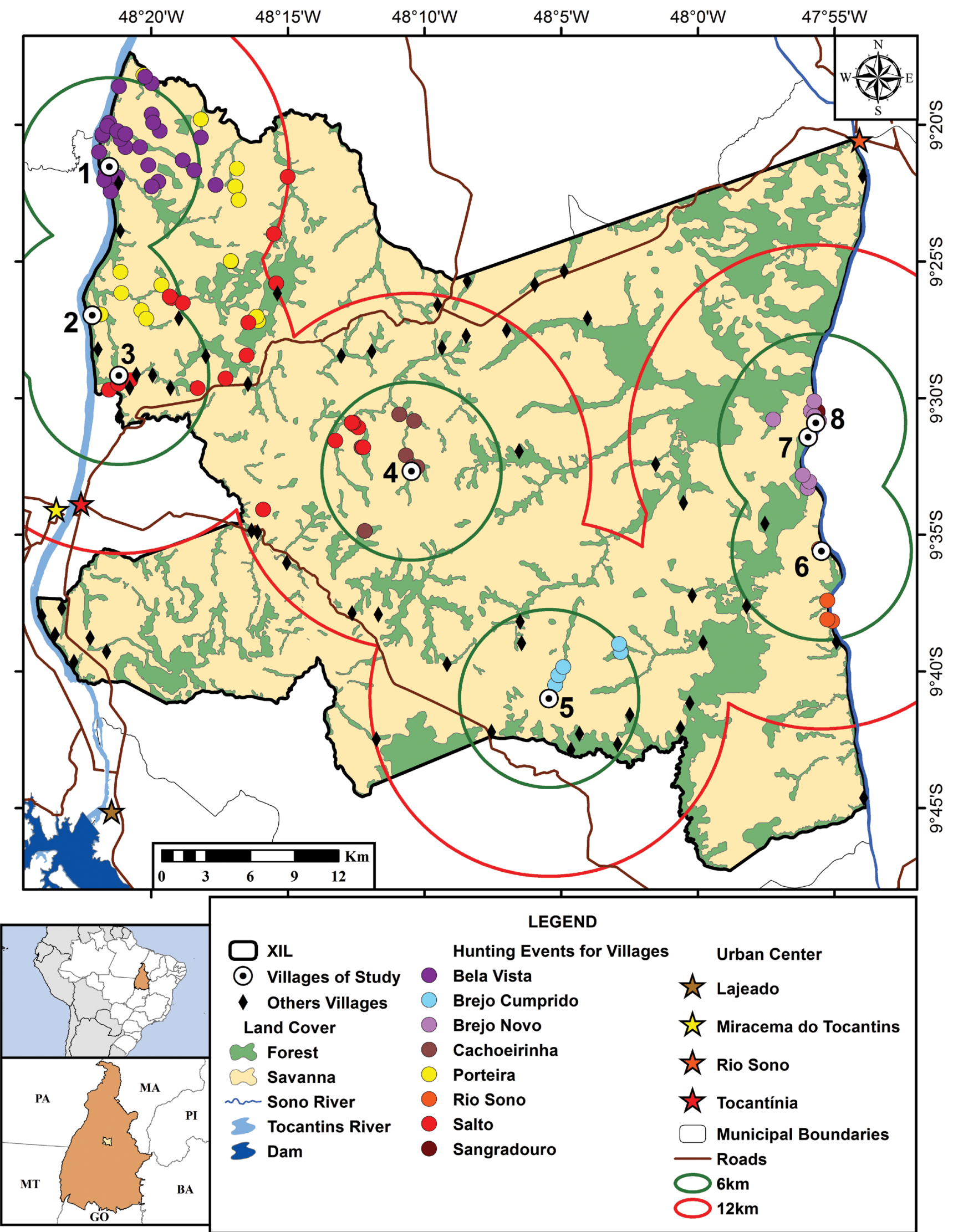

Figure 1. Locality of Xerente Indigenous Land and locations of hunting events. Numbers indicate the villages selected for the study: (1) Bela Vista; (2) Porteira; (3) Salto; (4) Cahoeirinha; (5) Brejo Cumprido; (6) Rio Sono; (7) Sangradouro; (8) Brejo Novo. 
deer), Pecari tajacu (collared peccary), Penelope superciliaris (rusty margined guan) and Tayassu pecari (white-lipped peccary). A total of 317 hunting events were included, for a total of 419 dead animals and an estimated 5583.85 kilograms of killed biomass. Opportunistic hunts (see de Paula et al. 2017) were not considered.

\section{Village data}

Distance $(\mathrm{km})$ between villages and the town of Tocantínia were measured with ArcGis 9.3. Distances were classified into the following categories: near: 8-13 Km; intermediate: $18-22 \mathrm{Km}$; farther: $31-48 \mathrm{Km}$ (Supplementary Material Table S1). This town was chosen because it is the main urban center influencing XIL. The Aage and size (number of families) of each village was collected in field (Supplementary Material Table S1).

\section{Preferred species}

We used semi-structured questionnaires whit hunters and nonhunters $(\mathrm{n}=104)$ to identify preferences based on taste categories: A: high level of preference; B: medium level of preference; C: low level of preference; D: very low level of preference. Species were then classified according to the category cited with the greatest frequency (\%). Furthermore, we classified all large prey $(\geq 30 \mathrm{~kg})$ as highly preferred, based on the principle that hunters always shoot this size class due to the high rate of meat return (Alvard 1993, Jerozolimski \& Peres 2003).

\section{Hunting event locations}

Monitors recorded the locations of 135 (42.5\%) hunting events. These locations were plotted in a Landsat 8 satellite with orbit 222 and point 67 (USGS 2014) of A3 size and 1: 115000 scale through participatory mapping (Read et al. 2010, Luzar et al. 2011, Constantino 2015). To facilitate the hunter's orientation, we utilized a GPS device to georeference several strategic locations (hunting area, villages, roads, and bridges), which were mapped and edited in ArcGis 9.3.2 software. The distance $(\mathrm{km})$ of each hunting event was measured by straight line from the point of hunt event to the central point of the hunter's village.

\section{Wet and dry season}

We used rainfall and average temperature data from nearby (c. 100 $\mathrm{km}$ ) weather stations to assess seasonality of the study area (INMET 2015). The dry season comprised some months with water deficit (Thornthwaite \& Mather 1955). Therefore, we calculated of the water balance for the entire period using formulas according to Rolim et al. (1998).

The period which presented water deficit comprised the months of May to October 2014 (Supplementary Material Figure S1), with March and April 2014 classified as a dry period. There was no water deficit from November 2014 to February 2015 (Supplementary Material Figure $\mathrm{S} 1$ ), therefore was classified as the rainy season.

\section{Data Analysis}

We used a Redundancy analysis (RDA) to evaluate the effects of the explanatory variables village age and size, distance of village to town and season on the composition and occurrence of hunted species. First, we observed and removed the collinearity among explanatory variables. It was considered collinearity when two variables had Pearson correlation above 0.70 . Only the distance of village to town and village size were correlated, and we maintain in the analysis only the distance of village for RDA. We used a logistic regression model to estimate the probability of hunting events related to distance. We consider the distance of $12 \mathrm{~km}$ a threshold of fauna depletion, indicating a long distance to hunt events. The distance of $12 \mathrm{~km}$ is in accordance with Read et al. (2010) in a study of the savannah environment in Guyana, as there are not yet any spatial parameters for hunting activities in the Brazilian Cerrado. Finally, we used a non-parametric Wilcoxon test to evaluate the effects of season on the number and biomass $(\mathrm{kg})$ of hunted animals. All analyses were carried out using R statistical software (R Development Core Team 2014).

\section{Results}

\section{Preferred species}

The most preferred species were paca and nine-banded armadillo (Table 1). Within the assemblyrange of hunted species, capybara, lowland tapir, red brocket deer and white-lipped pecary were also considered preferred sepecies due to their larger biomass (Table 1).

Table 1. Food preference of Xerente hunters. For the scientific names of species see Methods section. Xerente Indegenous Land. Tocantins, Brazil - Mar. 2014 to Feb. 2015.

\begin{tabular}{lcccc}
\hline \multirow{2}{*}{ Species } & \multicolumn{4}{c}{$\begin{array}{c}\text { Number of records for each category } \\
\text { of food preference (\%) }\end{array}$} \\
& A & B & C & D \\
\hline Agouti & - & 2 & 8 & 18 \\
Brazilian tapir*¥ & - & 16 & 30 & 8 \\
Brown brocket deer & - & 4 & 4 & 14 \\
Capybara*\# & - & - & 2 & 6 \\
Nine-banded armadillo & 6 & 34 & 2 & 10 \\
Paca & 64 & 12 & 12 & 2 \\
Pampas deer* & 4 & 12 & 22 & 10 \\
Red brocket deer*\# & 4 & 12 & 22 & 10 \\
Collared peccary & - & - & - & 16 \\
White-lipped peccary*¥ & 10 & 12 & 2 & 12
\end{tabular}

* Species with large body mass (> $30 \mathrm{~kg})$; \# Average weight of individuals estimated in Participatory Monitoring of Hunting in Xerente Indigenous Land; $¥$ Average body mass according Peres \& Palacios (2007).

\section{Game composition}

Distance from village to town and season affected the composition of hunted species (Table 2). Preferred species were killed more frequently by hunters from villages near $(8-13 \mathrm{~km})$ to town, with capybara the only exception (Figure 2). During the dry season the predominant hunting events involved red brocket deer, paca, agouti, collared peccary and capybara. The lowland tapir was killed exclusively in this period (Figure 3). Hunting of the remaining species was almost evenly distributed between the two seasons. 
Table 2. Results of Redundancy Analysis (RDA) for distance of villages to town and season (rainy and dry) in relation to game-species composition. Xerente Indigenous Land. Tocantins, Brazil - Mar. 2014 to Feb. 2015.

\begin{tabular}{lccccc}
\hline Source of variation & DF & SS & F & $\mathbf{R}^{\mathbf{2}}$ & $\boldsymbol{P}$ \\
\hline Distance & 1 & 21,33 & 4,484 & 0,22 & 0,004 \\
Season & 1 & 13,788 & 2,898 & 0,14 & 0,033 \\
Residue & 13 & 61,845 & - & - & - \\
\hline
\end{tabular}

48

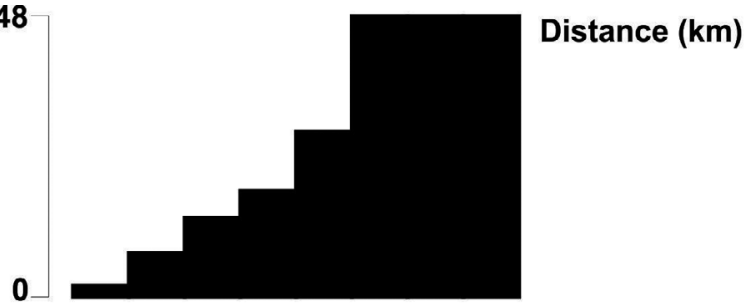

0



Figure 2. Relationship between the composition of game-species and distance of villages to town. *Preferred species. For the scientific names of species see Methods section.

\section{Distance of hunting events}

The probability of hunting events occurring father from villages $(>12 \mathrm{~km}$ ) increased in villages closer to town ( $p<0.001$, Fig. 4). Salto and Porteira villages, which are near to town and are also the most populous (Supplementary Material Table S1), present the highest probability of hunting events occurring farther than $12 \mathrm{~km}$, giving a strong indication of game-species depletion close to these villages. In these villages, $58 \%(n=33)$ of the georeferenced events were in areas greater in distance than $12 \mathrm{~km}$ (Figure 1), with the greatest distance occurring $17.55 \mathrm{~km}$ from Salto village. For the remaining villages, georeferenced events $(\mathrm{n}=75)$ were undertaken within $12 \mathrm{~km}$, with $93 \%(\mathrm{n}=70)$ occurring from 0 to $6 \mathrm{~km}$ (Figure 1$)$.

\section{Number and biomass killed}

Most hunting events occurred during the dry season $(67 \%, \mathrm{n}=212)$. Season affected the number of killed animals $(\mathrm{z}=2.52 ; \mathrm{p}=0.011)$ and biomass $(z=2.24 ; p=0.025)$. Hunting events were more frequent in the dry season $(35 \pm 28.67, \mathrm{n}=280)$, compared with the rainy season $(17.37 \pm 15.61, n=139)$ (Supplementary Fig. S2). Biomass was also greater in the dry season, with an average of $511.47 \mathrm{~kg} \pm 572.74 \mathrm{~kg}$ (n $=4,091.8 \mathrm{~kg}$ ), more than twice that of the rainy period average of 186.5 $\mathrm{kg} \pm 172.01 \mathrm{~kg}(\mathrm{n}=1,492.05 \mathrm{~kg})$ (Supplementary Material Figure S2).

\section{Discussion}

The difference in the composition of hunted species in relation to distance from village to town, with the highest availability of preferred species in villages nearest to town, may be an effect of the greater number of hunting events held by these villages (Supplementary Material Table S1), as non-preferred and smaller sized species were also more available. They are most populous and have more hunters, and consequently hold more hunting events. However, these villages present strong indications of game-species depletion within their proximity. Fauna depletion close to villages/settlements is indicative of low availability or absence of preferred species in hunted species assembly (Jerozolimski \& Peres 2003, Constantino et al. 2008, Read et al. 2010, Parry \& Peres 2015, Constantino, 2015, 2016). However, our results showed the opposite of these scenarios.

Currently, the Xerente hunters have great mobile capacity, through the use of bicycles, motorcycles or cars/tractors/trucks (motorcycles are predominant). This allows hunting to be conducted in remote areas ( $>$ 40 km, M. J. de Paula, personal observation), which otherwise could not be accessed by walking in a hunt where the individual returns home the same or next day. The use of these vehicles allows access to more suitable areas with higher concentrations of game-species (Read et al. 2010), and is facilitated by an extensive network of vicinal roads (most are state roads), thus eliminating the depletion effect of species close to the villages (Souza-Mazurek et al. 2000). However, this facility of locomotion may increase the depletion of an area (Benítez-López et al. 2017). One aggravating factor is illegal hunting by hunters that live around the XIL. This creates an undetectable impact which can place extensive pressure on fauna (Benítez-López et al. 2017).

As the number of killed animals and biomass was greater during the dry season, this indicates an intensification of hunting activities during this season. This increase in number of events is due to many Xerente hunters showing a preference for employing the waiting technique in this period (de Paula et al. 2017); called by many the "waiting period". This happens because there is fruit drop, mainly of "mirimdiba" (Buchenavia tomentosa Eichler), whose fruits attract species such as paca and the nine-banded armadillo, in addition to large bodied species such as lowland tapir and red brocket deer. As red brocket deer, capybara, and 




Figure 3. Relationship between the composition of game-species and the wet and dry season. For the scientific names of species see Methods section.



Figure 4. Effect of distance of village to town on the probability of hunting events occurring more than $12 \mathrm{~km}$ from the villages. lowland tapir deaths are concentrated in the dry season, this helps to explain the notable difference in biomass averages between the two seasons, as the added biomass of these species represents $39 \%(\mathrm{n}=$ $2171.5 \mathrm{~kg}$ ) of the total killed biomass. The increase in hunting effort during the dry season was also observed in the Xavante (Leeuwenberg \& Robinson 1999, Fragoso et al. 2000, Welch et al. 2013), who present great cultural affinities with the Xerente (Maybury-Lewis 1965) and also inhabit the Cerrado biome. However, this increase in hunting effort in the case of the Xavante is related to the use of fire in hunting, due to favorable conditions during this period (e.g. absence of rain).

The difference in game-species composition between seasons is reflective of the strategy to concentrate hunting activities in the dry season, which seems to be influenced by the phenological cycles of some plants. Even with strong indications of fauna depletion close to some villages, and the high mobility of the Xerente possibly increasing 
the depletion of an area, hunting pressure was different over time. The dynamics of natural phenomena such as season and flood pulse can have a direct effect on the exploitative pattern of fauna (Endo et al. 2016). The remarkable seasonality of the study area affected hunting activities and indicates an informal management practice that is seasonally regulated for some species, such as capybara, lowland tapir, paca and red brocket deer. This may contribute to the conservation of these species, and is more important in the case of the lowland tapir and red brocket deer, as these species are considered more sensitive to hunting and tend to be the first to suffer depletions due to overexploitation (Bodmer et al. 1997, Peres \& Palacios 2007). Additionally, the impact of undetected hunting is a threat to informal management, and intensive law enforcement is necessary to decrease illegal hunting in XIL.

Today, the Xerente are not exclusively dependent on wild meat as many have jobs, receive scholarships or "Bolsa Família" from the government, and have relatively good access to cattle and chicken meat and others protein sources such as fishing. The uptake of occupations (jobs or studies) limits hunting actives (M.J. de Paula, personal observation), as the "Tupinambá de Olivença" indigenous (Pereira \& Schiavetti 2010), and decreases the pressure on game-species. Hunting is an essential concept in the word-view and social organization of indigenous people (Shepard 2014). Even though economic factors are influencing a decrease in hunting, this activity still plays an essential role in maintaining the traditional culture of the Xerente people.

Our analysis shows that villages near the town present strong indications of game-species depletion close to these villages. However, the high mobility of hunters can eliminate this effect. This can explain the proportion of preferred game-species in these villages. Differences in game-species composition and hunting pressure between seasons can avoid the overexploitation of some sensitive species, such as low-land tapir. We argue that local management and conservation plans must take into consideration these issues beyond the cultural aspect involved in hunting. Enforcement of the law is also necessary to reduce the threat of illegal hunting, often present in XIL. The Xerente have access to other protein sources, however the practice of hunting is essential in maintaining their traditional culture. Finally, this study is also an attempt to better understand the wildlife exploitation mechanisms of the Cerrado biome, a priority area for conservation of global biodiversity (Myers et al. 2000), but as yet are not generally investigated in this aspect.

\section{Supplementary material}

The following online material is available for this article:

Table S1 - Villages of the study area with the respective numbers of age, distance to town, families, hunters and hunting events.

Figure S1 - Water balance of Xerente Indigenous Land for the study period (Mar. 2014 to Feb. 2015).

Figure S2 - Box plot between the mean number of animals killed and biomass killed in relation to the wet and dry season. A: animals killed; B: biomass killed.

\section{Acknowledgments}

We are sincerely grateful to all the Xerente hunters/monitors and other aids who participated in the study. We are thankful to the Akwẽ
Indígenous Association (AIA) and Indigenous Organization of Aldeia Ktẽpo Xerente (OIAKX). Thanks to J. M. V. Fragoso and E. Carvalho Jr for helpful comments on this manuscript. And thanks to two anonymous reviewers for helpful comments on this manuscript. Financial support for this study was provided by The Rufford Small Grants Foundation. The authors declare that they have no conflicts of interest related to the publication of this work.

\section{Author Contributions}

Milton José de Paula: The main responsible for the elaboration and execution of research and main responsible for manuscript elaboration.

Valcir Sumekwa Xerente: Contributed to the data collection and discussion, mainly in relation to the cultural aspects of the Xerente.

Aion Angelu Ferraz Silva: Contributed to the analyzes space of hunting events and discussion.

Bruno Spacek Godoy: Contributed to the statistical analyzes and elaboration of the text.

Juarez Carlos Brito Pezzuti: Is the general advisor and supervised all research.

\section{Conflicts of interest}

The authors declare that they have no conflict of interest related to the publication of this manuscript.

\section{References}

ALVARD, M.S. 1993. Testing the 'Ecologically Noble Savage' Hypothesis: Interspecific Prey Choice by Piro Hunters of Amazonian Peru. Human Ecology. 21: 355-387.

ALVARD, M.S., ROBINSON, J.G., REDFORD, K.H. \& KAPLAN, H. 1997. The sustainability of subsistence hunting in the Neotropics. Conservation Biology. 11: 977-982.

BENÍTEZ-LÓPEZ, A., ALKEMADE, R., SCHIPPER, A.M., INGRAM, D.J., VERWEIJ, P.A., EIKELBOOM, J.A.J. \& HUIJBREGTS, M.A.J. 2017. The impact of hunting on tropical mammal and bird populations. Science. 356: $180-183$.

BODMER, R.E., EISENBERG, J.F. \& REDFORD, K.H. 1997. Hunting and the Likelihood of Extinction of Amazonian Mammals. Conservation Biology. 11: $460-466$.

CONSTANTINO, P.A.L. 2015. Dynamics of hunting territories and prey distribution in Amazonian Indigenous Lands. Applied Geography. 56: 222-231.

CONSTANTINO, P.A.L. 2016. Deforestation and hunting effects on wildlife across Amazonian indigenous lands. Ecology and Society. 21: art3.

CONSTANTINO, P., FORTINI, L., KAXINAWA, F., KAXINAWA, A., KAXINAWA, E., KAXINAWA, L. \& KAXINAWA, J. 2008. Indigenous collaborative research for wildlife management in Amazonia: The case of the Kaxinawá, Acre, Brazil. Biological Conservation. 141: 2718-2729.

DE PAULA, M.J., XERENTE, V.S. \& PEZZUTI, J.C.B. 2017. Hunting and monitoring: community-based research in Xerente Indigenous Land, Brazilian Cerrado. Human Ecology Review. 23(1): 23-43

ENDO, W., PERES, C.A. \& HAUGAASEN, T. 2016). Flood pulse dynamics affects exploitation of both aquatic and terrestrial prey by Amazonian floodplain settlements. Biological Conservation. 201: 129-136.

ESCAMILLA, A., SANVICENTE, M., SOSA, M. \& GALINDO-LEAL, C. 2000. Habitat mosaic, wildlife availability, and hunting in the tropical forest of Calakmul, Mexico. Conservation Biology. 14: 1592-1601. 
FRAGOSO, J.M. V., SILVIUS, K.M. \& PRADA-VILLALOBOS, M. 2000 Integrando Abordagens Científicas e Indígenas de Manejo de Fauna em Áreas Indígenas: Avaliação e Manejo de Populações de Fauna Sujeitas à Caça na Reserva Xavante de Rio das Mortes, Mato Grosso. World Wildlife Fund - Brasil, Brasília.

HILL, K., PADWE, J., BEJYVAGI, C., BEPURANGi, A., JAKUGI, F., TYKUARANGI, R. \& TYKUARANGI, T. 1997. Impact of Hunting on Large Vertebrates in the Mbaracayu Reserve, Paraguay. Conservation Biology. 11: 1339-1353.

IBGE. 2010. Censo 2010. Http://www.censo2010.ibge.gov.br/terrasindigenas/ [accessed 2 July 2015].

INMET. 2015. Banco de Dados Meteorológicos para Ensino e Pesquisa (BDMEP). Http://www.inmet.gov.br/projetos/rede/pesquisa/ [accessed 10 September 2016].

IWAMURA, T., LAMBIN, E.F., SILVIUS, K.M., LUZAR, J.B. \& FRAGOSO, J.M. 2014. Agent-based modeling of hunting and subsistence agriculture on indigenous lands: Understanding interactions between social and ecological systems. Environmental Modelling \& Software. 58: 109-127.

JEROZOLIMSKI, A. \& PERES, C.A. 2003. Bringing home the biggest bacon: a cross-site analysis of the structure of hunter-kill profiles in Neotropical forests. Biological Conservation. 111: 415-425.

KOSTER, J.M. 2008. Hunting with Dogs in Nicaragua: An Optimal Foraging Approach. Current Anthropology. 49: 935-944.

LEEUWENBERG, F.J. \& ROBINSON, J.G. 1999. Traditional Management of Hunting by a Xavante Community in Central Brazil: The Search for Sustainability. In Hunting for Sustainability in Tropical Forest: (J.G. Robinson \& E.L. Bennett, eds.). Columbia University Press, New York, p. $375-393$.

LUZAR, J.B., SILVIUS, K.M. \& FRAGOSO, J.M. V. (2012) Church Affiliation and Meat Taboos in Indigenous Communities of Guyanese Amazonia. Human Ecology. 40: 833-845.

LUZAR, J.B., SILVIUS, K.M., OVERMAN, H., GIERY, S.T., READ, J.M \& FRAGOSO, J.M. V. 2011. Large-scale Environmental Monitoring by Indigenous Peoples. BioScience. 61: 771-781.

MAYBURY-LEWIS, D. 1965. Some Crucial Distinctions in Central Brazilian Ethnology. ANTHROPOS. 60: 340-358.

MILNER-GULLAND, E.J., BENNETT, E.L. \& GROUP, S. 2002 A.M.W.M. 2003. Wild meat: the bigger picture. Trends in Ecology \& Evolution. 18: 351-357.

MYERS, N., MITTERMEIER, R.A., MITTERMEIER, C.G., DA FONSECA, G.A. \& KENT, J. 2000. Biodiversity hotspots for conservation priorities. Nature. 403: 853-858.
NASI, R., BROWN, D., WILKIE, D., BENNETt, E., TUTIN, C., VAN TOL, G. \& CHRISTOPHERSEN, T. 2008. Conservation and use of wildlife-based resources: the bushmeat crisis. Secretariat of the Convention on Biological Diversity, Monteral, and Center for International Forestry Research (CIFOR). Bogor, Technical Series no. 33.

PARRY, L. \& PERES, C. 2015. Evaluating the use of local ecological knowledge to monitor hunted tropical-forest wildlife over large spatial scales. Ecology and Society. 20.

PEREIRA, J. P. R., \& SCHIAVETTI, A. 2010. Conhecimentos e usos da fauna cinegética pelos caçadores indígenas "Tupinambá de Olivença" (Bahia). Biota Neotropica. 10(1): http://www.biotaneotropica.org.br/v10n1/en/ abstract?article+bn03210012010. [accessed 29 March 2018]

PERES, C.A. \& PALACIOS, E. (2007) Basin-Wide Effects of Game Harvest on Vertebrate Population Densities in Amazonian Forests: Implications for Animal-Mediated Seed Dispersal. Biotropica. 39: 304-315.

R Development Core Team. 2014. A language and environment for statistical computing. R Foundation for Statistical Computing. Vienna, Austria.

READ, J.M., FRAGOSO, J.M. V, SILVIUS, K.M., LUZAR, J., OVERMAN, H., CUMMINGS, A. \& GIERY, S.T. 2010. Space, Place and Hunting Patterns among Indigenous Peoples of the Guyanese Rupununi. Journal of Latin American Geography. 9: 213-243.

RIBEIRO, J.F. \& WALTER, B.M. 2008. As principais fitofisionomias do Bioma Cerrado. In Cerrado: Ecologia e Flora (S.M. Sano, S.P. Almeida \& J.F. Ribeiro, eds). EMBRAPA, Brasília, p. 19-45.

SHEPARD, G.H. 2014. Hunting in Amazonia. In Encyclopaedia of the History of Science, Technology, and Medicine in Non-Western Cultures (H. Seline, ed). Springer Netherlands, Dordrecht, p. 1-77.

SHEPARD, G.H., LEVI, T., NEVES, E.G., PERES, C.A. \& YU, D.W. 2012. Hunting in Ancient and Modern Amazonia: Rethinking Sustainability. American Anthropologist. 114: 652-667.

SOUZA-MAZUREK, R.R., PEDRINHO, T., FELICIANO, X., HILÁRIO, W., GERÔNCIO, S. \& MARCELO, E. (2000) Subsistence hunting among the Waimiri Atroari Indians in central Amazonia, Brazil. Biodiversity and Conservation. 9: 579-596.

STRONG, J.N., FRAGOSO, J.M. V. \& OLIVEIRA, L.F.B. 2010. Padrões de uso e escolha de caça pelos índios macuxi em Roraima. In Roraima: Homem, Ambiente e Ecologia (R.I. Barbosa \& V.F. Melo, eds). FEMACT, Boa Vista, p. 631-644.

USGS. 2014. Landsat Missions. Http://landsat.usgs.gov/. [accessed 5 January 2014].

WELCH, J.R., BRONDÍZIO, E.S., HETRICK, S.S. \& COIMBRA Jr., C.E. 2013. Indigenous burning as conservation practice: neotropical savanna recovery amid agribusiness deforestation in Central Brazil. PloS one. 8: e81226. 